Международной научно-практической интерконференции. - Ростов-на-Дону, 2003. 15. Definition and Selection of Competencies. Theoretical and Conceptual Foundations (DESECO). Strategy Paper on Key Competencies. An Overarching Frame of Reference for an Assessment and Research Program OECD (Draft). 16. Tuning Educational Structures in Europe/ Line 1. Learning Outcomes/Competencies Methodology, 2001-2003. Phase 1. http://www. Relint. Deusto. es/Tuning Project/index.htm.

УДК 378.147:159.947.5

3. I. Cmуnак,

старший викладач,

Криворізький педагогічний інститут

ДВНЗ «Криворізький начіональний університет»

\title{
АНАЛІЗ НАВЧАЛЬНОЇ МОТИВАЦІЇ ЯК ОСНОВИ НАВЧАЛЬНО-ПІЗНАВАЛЬНОЇ ДІЯЛЬНОСТІ СТУДЕНТІВ
}

Ступак 3. І. Аналіз навчальної мотивації як основи навчально-пізнавальної діяльності студентів.

У статті на основі аналізу навчальної мотивації як основи навчально-пізнавальної діяльності студентів здійснено спробу виявити чинники, що впливають на вибір майбутньої спеціальності, а також мотивацію навчальної діяльності студентів.

Ключові слова: мотиви, мотивація, мотиваційна діяльність, потреби, процес навчання.

Ступак 3. И. Анализ учебной мотивации как основы учебно-познавательной деятельности студентов.

В статье на основе анализа учебной мотивации как основы учебно-познавательной деятельности студентов предпринята попытка выявить факторы, влияющие на выбор будущей специальности, а также мотивацию учебной деятельности студентов.

Ключевые слова: мотивы, мотивация, мотивационная деятельность, потребности, процесс обучения.

Stupak Z. I. Analyses of learning motivation as a basis for learning and cognitive activity of students.

On the basis of analysis of learning motivation as a basis for learning and cognitive activity of students attempted to identify factors that influence the choice of future profession, as well as the motivation of learning activities of students.

Key words: motives, motivation, motivational activities, needs, the process of learning.

Навчальна діяльність спрямована на оволодіння узагальненими способами дій у галузі наукових понять. Вона повинна спонукатися адекватними мотивами, що безпосередньо пов'язані 3 iï змістом: мотиви придбання узагальнених способів дій, мотиви самовдосконалення.

Початок XXI століття позначений активним пошуком шляхів реформування освітянської системи України. У вищій школі ця проблема розглядається переважно в аспекті відповідності навчальної діяльності до вимог стандартів освіти, переходу до іiі триступеневої системи (підготовка за рівнями бакалавра, спеціаліста та магістра). Меншою мірою звернено увагу на необхідність переосмислення мети, змісту, форм i методів підготовки фахівців, перегляду психолого-педагогічної парадигми освіти.

Метою статmі є аналіз навчальної мотивації як основи навчально-пізнавальної діяльності студентів, спроба виявлення чинників, що впливають на вибір майбутньої спеціальності, а також на мотивацію навчальної діяльності студентів.

За останні півстоліття у світі розроблено понад 50 мотиваційних теорій, за кожною 3 яких - сотні й тисячі досліджень.

Теоретичною основою нашого дослідження $є$ ідеї таких науковців, як: Л. Божовича, I. Дмитрієва, А. Дусавицького, А. Занкова, Б. Ельконіна, Л. Копець, К. Костючок, В. Лісовського, А. Матіс, Д. Ніколенко, М. Орлів, Л. Рубінштейна, Х. Хекхаузена, I. Якобсона, та ін.). Із-поміж дослідників передовсім варто зупинитися на працях із питань 
мотивації діяльності людини Є. Клайпереда, Д. Чармса, В. Франкла, Д. Брунера, Д. Карнегі, К. Мадсена, Д. Фрієра та інших.

Уперше термін «мотивація» запропонував А. Шопенгауер у статті «Чотири принципи достатньої причини» (1900-1910). Потім цей термін увійшов до складу психологічної лексики задля пояснення причин поведінки людини чи тварини.

Так, у відомих положеннях С. Рубінштейна мотивація визначається як психічна детермінація, К. Мадсена - як сукупність чинників, що спонукають, підтримують i спрямовують поведінку. Д. Фрієра - як енергетичний аспект досвіду і реакцій. Відповідно до думки багатьох західних психологів (У. Мак-Дауголл, Г. Олпорт, Г. Мюррей), мотивоване поводження людини переважно орієнтується щодо об'єкта - мети.

Р. Мак-Івер визначає мотиви як ефективні оцінки, які визначають поведінку і приховано змінюють наші інтереси і ставлення; Х. Хекхаузен говорить про те, що мотивація є процесом перетворення спонукання на дію. Д. Кікнадзе - як знання суб'єктивної необхідності тієї чи тієї дії; П. Якобсон зазначає, що мотив зумовлює спрямовану поведінку людини, створює установку до дії, спонукає до діяльності. С. Рубінштейн розглядає ситуаційні мотиви, які визначаються не стільки внутрішньою логікою людини, скільки збігом зовнішніх обставин, взаємодіють із власне інтелектуальними, пізнавальними мотивами.

А. Маслоу було запропоновано класифікацію людських потреб за ієрархічно побудованими групами, послідовність яких указує на порядок появи загалом мотиваційної сфери. Згідно з нею основою мотивів $є$ потреби [4].

Дослідники спільним знаменником мають думку, яка полягає в тому, що за мотив слід приймати якийсь один конкретний психологічний феномен (але різний у різних авторів).

Здійснивши теоретичний аналіз психолого-педагогічної літератури, можемо стверджувати, що генетичною основою мотивів діяльності $€$ різні потреби людини первинні (природні) і вторинні (матеріальні та духовні). Унаслідок усвідомлення та переживання цих потреб у людини виникає певне спонукання до дії, завдяки якому ці потреби задовольняються. Потреба, усвідомлена людиною, може сама становити спонукання до дії, тобто бути мотивом. Зміст потреб відображається у формі почуттів, думок, понять, ідей, уявлень, переконань, ідеалів, інтересів тощо, що за певних обставин становлять спонукання до дії та вчинків людини, - це допитливість, потяг до знань, потреба розумової діяльності, пізнання, розширення знань про довкілля, прагнення отримати нові знання й навчитися їх застосовувати, вдосконалювати свої пізнавальні можливості, розвивати інтелектуальні здібності.

Основною загальною ознакою цих мотивів $\epsilon$ те, що їх утворює і формує процес здобуття знань, умінь і навичок, який розвиває кмітливість і винахідливість, удосконалює уміння і навички. Студенти отримують задоволення від інтелектуальних зусиль під час виконання навчальних завдань.

На становлення інтелектуальних почуттів як мотивів навчальної діяльності значно впливає формування пізнавальних інтересів, оволодіння студентами інтелектуальними уміннями, розвиток потреби доводити, пояснювати ті чи ті положення, а також формування наукового світогляду і переконань. Але це в свою чергу, залежить від якості викладання, методів навчання, організації взаємодії, співпраці та індивідуальної роботи зі студентами і багато інших суб'єктивних та об'єктивних чинників.

Важливу роль у формуванні пізнавальних мотивів посідає суб'єктивна готовність студентів виконувати навчальні завдання, які постійно ускладнюються, певна розвиненість пізнавальних потреб, розумових здібностей, міра оволодіння прийомами самостійної розумової діяльності, уміння розподіляти свій час і організовувати власну роботу тощо.

До іншого виду мотивів навчальної діяльності відносимо ті, що за походженням і змістом начебто виходять за межі навчального процесу i пов'язані 3 широкими суспільними взаємовідносинами (не відставати від своїх товаришів, бути як усі, отримувати гарні оцінки, отримати професію, що має попит на ринку праці. 
Мотиви другого виду - соціальні - формуються під впливом сім’ї, навколишніх, навчально-виховного процесу. У цьому сенсі навчання постає певною формою участі в житті суспільства.

Для успішного здійснення навчальної діяльності необхідні позитивні мотиви як першої, так і другої категорії. Широкі соціальні мотиви утворюють основу для того, щоб навчання йшло успішно та рівно, оскільки навчальна робота не може бути завжди і у всьому цікавою (заучування правил, дат тощо). Така праця може i повинна спонукатися широкими соціальними мотивами: усвідомленням обов'язку, прагненням стати науковцем, учителем тощо.

Однак за наявності тільки таких узагальнених мотивів навчання може позбавитись безпосереднього живого інтересу, привабливості. Тому широкі узагальнені мотиви і власне навчальні мотиви (інтереси) повинні бути внутрішньо пов’язаними, складати єдину систему.

Виокремлюють форми мотивації, де важливу роль відіграють соціальні прагнення особистості: перша форма пов'язана 3 достатньо гострим переживанням почуття громадянського обов'язку перед країною, близькими; пов'язана з уявленням про навчання як про шлях до засвоєння великих цінностей культури, як про засіб, що дозволяє у більш цінній формі зробити людям корисне, з уявленням про навчання як шлях до здійснення свого призначення в житті.

Ставлення до навчання робить його не просто необхідним, але й привабливим у певному розумінні. Однак якщо в процесі навчання ця установка не буде підкріпленою іще й іншими мотивувальними чинниками, то вона не забезпечить максимального ефекту, оскільки володіє привабливістю не діяльність, як така, а лише те, що пов'язане з нею.

Друга форма - мотивація визначається не широкими соціальними, а вузькоособистими мотивами. Процес навчання сприймається як шлях до особистого благополуччя, як можливість створити собі відповідний соціальний стан серед оточуючих. Ця мотивація в силу низки психологічних причин не має такої спонукальної сили як широка соціальна мотивація, що мобілізує ціннісні аспекти особистості, оскільки мотиви навчання, що визначаються вузькоособистими прагненнями, часто не забезпечують досягнення такого ефекту.

Третя форма мотивації закладена в процесі навчальної діяльності. Спонукає вчитися, оволодівати певним колом знань, умінь, навичок сам процес набуття знань. В основі прагнення оволодіння знаннями покладено допитливість, нестримне прагнення пізнаннч нового. У процесі навчання відчувається задоволення від захоплення, допитливості, усвідомлення розширення власних перспектив у сенсі ознайомлення 3 дійсністю, відкриттям для себе невідомих раніше аспектів. Ці форми мотивації навчання ніколи не реалізуються у чистому вигляді. Фактично мотиви навчання завжди мають більш складний характер.

Завдання викладача полягає в тому, щоб розвивати позитивну мотивацію, прагнення особистості до знань, удосконалення своєї діяльності та культури, яка грунтується на стійких пізнавальних інтересах.

Нідерландський науковець М. Лангвельд розглядає чинники, які сприятливо або несприятливо впливають на формування особистості вчителя [6]. Дослідник особливу увагу приділяє аналізу других, оскільки саме це може пояснити причини неуспіху в педагогічній діяльності і допомогти виявити методи ефективного відбору абітурієнтів. До числа несприятливих чинників, які можуть привести до професійної нестійкості, він відносить такі: вибір професії вчителя як тієї, що, за панівною думкою, забезпечує легку роботу; вибір на основі припущення про наявність у вчителя вільного часу; вибір за порадою батьків, які мало знають про сутність інтелектуальних професій, а про окреслену судять із власного досвіду; прагнення до володіння престижем учителя в більш низькому соціальному середовищі; прагнення до отримання професії вчителя у зв’язку з іiі 
фінансовою доступністю; прагнення піднятись завдяки оволодінню професії вчителя на більш високий соціальний щабель.

До числа сприятливих мотивів вибору професії вчителя науковець відносить такі: вибір іiї завдяки позитивному досвіду, одержаному в школі; вибір завдяки інтересу до певного навчального предмета і свідомому прагненню допомогти учням розкрити їхні інтереси i навчити самостійно мислити, аналізувати; вибір завдяки прагненню до соціальних ідеалів.

Одним із методів нашого дослідження було анкетування вчителів та студентів. Питання, запропоновані вчителям, відносно мотивів вибору професії були такими: «Школа переживає важкі часи. Багато вчителів залишають ії. Укажіть, чим Вас утримує школа нині?». Відповіді розподілились так (табл. 1).

Розподіл мотивів вибору професії

Таблиия 1

\section{вчителями та студентами-випускниками університету (у \%)}

\begin{tabular}{|c|c|c|c|c|c|c|c|}
\hline \multirow[t]{2}{*}{$\begin{array}{l}\text { № } \\
\Pi / \Pi\end{array}$} & \multirow{2}{*}{$\begin{array}{c}\text { Мотиви } \\
\text { вибору } \\
\text { професії }\end{array}$} & \multicolumn{4}{|c|}{ Учителі зі стажем } & \multicolumn{2}{|c|}{$\begin{array}{c}\text { Студенти КПІ ДВНЗ } \\
\text { «КНУ» }\end{array}$} \\
\hline & & $\begin{array}{l}\text { До 3-х } \\
\text { років } \\
\text { (40осіб) }\end{array}$ & $\begin{array}{c}3-10 \\
\text { років } \\
(45 \text { осіб) }\end{array}$ & $\begin{array}{c}10-20 \\
\text { років } \\
(56 \text { осіб) }\end{array}$ & $\begin{array}{c}20 \text { років } \\
\text { та } \\
\text { більше } \\
\text { (56 осіб) } \\
\end{array}$ & $\begin{array}{c}\text { Муз-пед } \\
\text { क-т } \\
(20 \text { осіб) }\end{array}$ & $\begin{array}{c}\text { Педагогічний } \\
\phi-т \\
\text { (60 осіб) }\end{array}$ \\
\hline 1 & $\begin{array}{ll}\text { Інтерес } & \text { та } \\
\text { любов до } & \\
\text { дітей } & \end{array}$ & 20,0 & 66,0 & 45,0 & 54,0 & 50,0 & 35,7 \\
\hline 2 & $\begin{array}{r}\text { Творчий } \\
\text { характер } \\
\text { професії }\end{array}$ & 20,0 & 17,6 & 39,6 & 25,2 & 45,0 & 28,9 \\
\hline 3 & $\begin{array}{l}\text { Довготривала } \\
\text { відпустка }\end{array}$ & 20,0 & 8,80 & 25,2 & - & 10,0 & 3,4 \\
\hline 4 & $\begin{array}{l}\text { Можливість } \\
\text { реалізувати } \\
\text { свої лідерські } \\
\text { домагання }\end{array}$ & - & 4,40 & - & - & 10,0 & - \\
\hline 5 & $\begin{array}{l}\text { Гарантоване } \\
\text { працевлаштува } \\
\text { ння }\end{array}$ & 30,0 & 17,6 & 18,0 & 18,0 & 5,0 & 8,5 \\
\hline 6 & $\begin{array}{l}\text { Можливість } \\
\text { впливати на } \\
\text { підростаюче } \\
\text { покоління }\end{array}$ & 10,0 & 4,40 & 18,0 & 19,8 & 20,0 & 15,3 \\
\hline
\end{tabular}

Примітка : Окремі респонденти вказували не один, а 2-3 мотиви.

Опитування показало, що більшість учителів головним мотивом вибору професії діяльності називають інтерес і любов до дітей. Найбільшу значущість для себе творчого характеру професії показала група вчителів зі стажем від 10 до 20 років. Можливість керувати виокремлюють лише 4,40 \% учителів у групі зі стажем від 3-х до 10 років. Уважаємо, що необхідна спеціальна робота, щоб це бажання не утвердило в них авторитарності. Робота в школі через хвилювання не знайти іншу стала основним мотивом вибору у 30,0\% учителів зі стажем до 3-х років. Це достатньо високий відсоток «випадкових» людей у школі, які також потребують спеціальної уваги. Суспільно значущий мотив - важливість справи, яку виконує вчитель, можливість впливати на підростаюче покоління - керує вчителем зі стажем 20 років та більше - 19,8 \% вибору, стаж від 10 до 20 років - 18,0\%. У групах молодих учителів цей мотив незначно виражений - $10,0 \%$ та 4,40\%. Причину цього значною мірою ми бачимо у складності соціального становища в країні, падінні престижу професії вчителя. 
Таке саме питання було задане студентам. Випускники КПІ ДВНЗ «Криворізький національний університет» головним мотивом назвали, як і вчителі, інтерес та любов до дітей - 50 \% та 35,7 \% вибору. Значний відсоток студентів (45,0\% випускників музичнопедагогічного факультету та 28,9 \% випускників педагогічного факультету) уважає роботу творчою й цікавою. Однак, на факультетах малий відсоток упевнених у своїх можливостях забезпечити позитивний вплив на підростаюче покоління (відповідно 20,0 \% та 15,3\%). Особливо турбує той факт, що все-таки 3-поміж випускників $є$, хоч і незначна кількість (відповідно 5,0 \% та 8,5 \%), тих, кого робота у школі не приваблює.

Проаналізувавши відповіді респондентів, зазначимо, що проблема мотивації професійної діяльності перебуває в тісному зв'язку з ефективністю відбору абітурієнтів та подальшим формуванням стійкого позитивного ставлення до обраної професії. За умови, коли має місце чинник випадковості, результатом може бути або відплив молодих учителів зі шкіл, або негативні результати педагогічної діяльності.

Отже, можна стверджувати, що результат педагогічної діяльності стане ефективнішим, якщо буде задіяно весь спектр позитивної мотивації. Квінтесенцією такої роботи має стати розвиток мотиваційної оріснтації студента на успішність навчальної діяльності 3 наголосом на її процес та результат, а не на єдиний метод «залякування» неотриманням бажаної оцінки, заліку, стипендії, закінчення курсу чи освіти в цілому з боку викладачів та адміністрації і відповідну реакцію студента - будь що уникнути таких «неприємностей».

\section{Література}

1. Балакірєва О. Ціннісні орієнтації молодого покоління / О. Балакірєва, О. Яременко // Молодь у дзеркалі соціології. - К. : УІСД, 2001. - С. 38-47. 2. Борис I. Мотиваційна сфера як проблемний чинник поведінки / І. Борис // Психологія і суспільство. - Тернопіль: Інститут експериментальних систем освіти. - 2002. - № 2. - С. 48-57. 3. Ильин Е. П. Мотивация и мотивы : [учебник] /Е. П. Ильин. - М. : Питер, $2002-508$ с. 4. Маслоу А. Мотивация и личность / А. Маслоу. - М. : Питер, 2007. - 351 с. 5. Скляр П. Мотивація навчальної діяльності студентів / П. Скляр // Соціальна психологія. - 2004. - № 5 (7). - С. 95-108. 6. Langveld M. I. The Psycholoqic of Teachers and the Teachering Profession. State University of Utrecht. The Ycar Boor of Education, 1963.

УДК $371.134: 373.3$

I. O. Талаш, кандидат філол. наук, Криворізький педагогічний інститут ДВНЗ «Криворізький національний університет»

\section{АКТИВІЗАЦІЯ ПІЗНАВАЛЬНОЇ ДІЯЛЬНОСТІ МАЙБУТНІХ УЧИТЕЛІВ ПОЧАТКОВИХ КЛАСІВ}

Талаш І. О. Активізація пізнавальної діяльності майбутніх учителів початкових класів.

У статті зроблено спробу окреслити шляхи активізації пізнавальної діяльності студентів психолого-педагогічного факультету у процесі впровадження модульно-рейтингової технології навчання.

Ключові слова: пізнавальна активність, пізнавальні мотиви, модуль, блок, модульно-рейтингова технологія.

Талаш И. А. Активизация познавательной деятельности будущих учителей начальных классов.

В статье осуществлена попытка определить пути активизации познавательной деятельности студентов психолого-педагогического факультета в процессе внедрения модульно-рейтинговой технологии обучения.

Ключевые слова: познавательная активность, познавательные мотивы, модуль, блок, модульнорейтинговая технология.

Talash I. O. Activization of cognitive activity of future primary school teachers. 